\title{
Terytorialny paradygmat rozwoju w praktyce
}

\section{Monika Słupińska}

\begin{abstract}
STRESZCZENIE
Polityka spójności odgrywa kluczową rolę dla dynamiki procesu integracji europejskiej, stanowi w pewnym sensie „barometr" siły i kierunku przebiegu tego procesu, wokół którego w ostatnich latach toczy się debata europejska. Polityka ta w obecnym okresie programowania (2014-2020) ma wyraźny „wymiar terytorialny“, tzn. pozwala na dopasowanie charakteru wsparcia do specyfik i potrzeb określonych terytoriów.

Celem niniejszego artykułu jest zwrócenie uwagi na istotę koncepcji terytorialnego paradygmatu rozwoju oraz wskazanie przykładów jego aplikacji przez polityki rozwoju. Szczególna uwaga w tym kontekście została poświęcona europejskiej polityce spójności, której polskie regiony są największym beneficjentem.
\end{abstract}

\section{Wprowadzenie}

Polityka spójności odgrywa kluczową rolę dla dynamiki procesu integracji europejskiej, stanowi w pewnym sensie „barometr” siły i kierunku przebiegu tego procesu, wokół którego w ostatnich latach toczy się debata europejska ${ }^{1}$.

Polityka spójności realizowana przez Unię Europejską w ostatnich latach stopniowo odchodzi od modelu polityki redystrybucyjnej, ewoluując w kierunku polityki ukierunkowanej na wykorzystanie potencjałów endogenicznych i specyfik poszczególnych terytoriów. Tym samym polityka spójności koncentruje się na coraz większym wykorzystaniu potencjału rozwojowego całej Unii Europejskiej, a w jej programowaniu i realizacji wymiar terytorialny nabiera rosnącego znaczenia.

W okresie programowania 2014-2020 realizowana przez Unię Europejską polityka spójności w sposób wyraźny nawiązuje do dorobku badawczego, który eksponuje terytorialny charakter procesów rozwoju². Przyjęcie tezy o roli terytorium w rozwoju jest konsekwencją przyjęcia dorobku naukowego eksponującego rolę środowisk i zasobów lokalnych, stanowiących specyficzną bazę dla rozwoju lokalnego. Podejście ukierunkowane terytorialnie winno cechować się lepszym wykorzystaniem ukrytych lub niewłaściwie wykorzystywanych zasobów i specjalizacji terytorialnych wszystkich terytoriów. Podejście to wymusza większą i lepszą koordynację wszystkich polityk sektorowych mających oddziaływanie terytorialne i ich stałą ocenę wpływu na terytorium (np. polityka rolna, transportowa ${ }^{3}$ ).

\footnotetext{
${ }^{1}$ Więcej na temat związków pomiędzy polityką spójności a modelami integracji europejskiej zawiera artykuł autorki - M. Słupińska 2012 a.

${ }^{2}$ Wypracowane w tym zakresie koncepcje teoretyczne rozwoju regionalnego, mi.in. koncepcja rozwoju sieciowego (Castells 2008), koncepcja regionu uczącego się (Florida 1995), czy nowa teoria wzrostu endogenicznego (Romer 1994, za: Szlachta i Zaleski 2009), stanowią teoretyczną podstawę programowania i wdrażania polityki spójności Unii Europejskiej.

${ }^{3}$ Polityki sektorowe powinny wykorzystywać potencjał i doświadczenie polityki regionalnej w zakresie budowania podejścia terytorialnego i zintegrowanego, a także aplikować zasadę partnerstwa umożliwiającą pełniejsze wykorzystanie
} 
Jedna z prekursorek upowszechniania terytorialnego paradygmatu rozwoju w Polsce, I. Pietrzyk, definiuje terytorium jako specyficzną konstrukcję społeczna, opartą na wspólnej dla danej społeczności historii, kulturze, wiedzy i umiejętnościach [Pietrzyk 2004, s. 12-13], natomiast A. Jewtuchowicz postrzega terytorium jako podmiot charakteryzujący się własną logiką organizacyjna, której efektywność może stanowić stymulant lub barierę dla rozwoju przedsiębiorstw w nim ulokowanych [Jewtuchowicz 2005, s. 63-66].

R. Camagni zauważa, że: "(..) aktualne badania zdecydowanie potwierdzaja, że pojęcie "terytorium" jawi sie jako trafniejszy termin od abstrakcyjnego pojęcia "przestrzeni”, w odniesieniu do nastęujących elementów:

- system zlokalizowanych korzyści zewnętrznych, zarówno pieniężnych (gdzie korzyści z nich sq realizowane poprzez transakcje rynkowe), jak i technologicznych (gdzie korzyści uzyskiwane sa ze względu na sama fizyczna bliskość ich źródła);

- system zlokalizowanych praktyk, tradycji, umiejętności i know-how;

- system zlokalizowanych relacji bliskości, które tworza "kapitat” - natury społeczno-psychologicznej i politycznej - a tym samym wzmacniaja statyczna i dynamiczna produktywność lokalnych czynników;

- system elementów kulturowych i wartości, które nadaja sens i znaczenie lokalnym praktykom i strukturom oraz definiuja tożsamości lokalne; nabieraja one znaczenia gospodarczego każdorazowo, kiedy moga być przetworzone na produkty rynkowe - dobra, usługi lub aktywa - lub też wzmacniaja wewnętrzna zdolność do wykorzystania lokalnych potencjatów;

- system zasad i praktyk definiujących lokalne modele rządzenia" [Camagni 2008, s. 37].

Jednym z podstawowych czynników rozwoju lokalnego - wyznaczanych przez terytorialny paradygmat rozwoju - są społeczności lokalne, sposób ich zorganizowania, formalne i nieformalne instytucje, reguły, sposoby zarządzania rozwojem lokalnym ukształtowane w procesie historycznego rozwoju terytorium i społeczności naznaczonej wspólnotą doświadczeń [Słupińska 2016, s. 26]. Przyjęcie terytorialnego paradygmatu rozwoju za podstawę rozważań nad procesami rozwoju regionalnego implikuje konieczność skoncentrowania się na kluczowych elementach budujących terytorium. W badaniach poświęconych rozwojowi gospodarczemu jednostek terytorialnych coraz częściej eksponowana jest rola tzw. miękkich uwarunkowań rozwoju lokalnego, takich jak: kapitał społeczny, kapitał kulturowy czy system rządzenia [Barczyk 2010, s. 134].

Największy wpływ na obecny kształt polityki spójności miało opublikowanie w 2009 roku raportu Fabrizia Barki, którego opracowanie zleciła ówczesna komisarz ds. polityki regionalnej, Danuta Hübner. Barca do pracy nad koncepcją reformy polityki spójności zaprosił zarówno przedstawicieli świata nauki, jak i urzędników państw członkowskich UE odpowiedzialnych za programowanie i wdrażanie polityki spójności. Jak zauważa I. Pietrzyk, Barca w swoim raporcie obalił szereg obiegowych opinii na temat polityki spójności, negujących jej zasadność oraz w sposób merytoryczny uzasadnił konieczność jej dalszej kontynuacji. Powszechna krytyka polityki spójności dotyczyła m.in. sprowadzania jej wyłącznie do funkcji redystrybucyjnych, postępującej jej „lizbonizacji” (preferowanie po-

zaangażowania wszystkich podmiotów w procesie rozwoju społecznego, gospodarczego i terytorialnego. 
stulatu konkurencyjności nad solidarnością) oraz - co najważniejsze - uznawania jej za zbyt kosztowną i zmniejszającą ogólną efektywność ekonomiczną w stosunku do pozytywnie przekładającej się na konkurencyjność przestrzennej koncentracji rozwoju. W raporcie wskazywano konieczność prowadzenia takiej polityki spójności, która uwzględnia często bardzo zróżnicowane specyficzne warunki poszczególnych obszarów i która opierać się będzie na nowoczesnych metodach zarządzania procesami rozwoju, przede wszystkim na wielopoziomowym zarządzaniu - multi-level governance [Pietrzyk 2013, s. 150-151].

Ewolucja polityki spójności odchodzi zatem od dotychczasowego modelu redystrybucji środków do regionów mniej uprzywilejowanych na rzecz wspierania rozwoju wewnętrznych mechanizmów i czynników rozwoju społeczno-gospodarczego. Jak najlepsza i jak najwłaściwsza droga do zdefiniowania możliwości i potrzeb określonych obszarów narzuca konieczność ścisłej współpracy z samorządami terytorialnymi w celu określenia szczegółowych celów interwencji publicznej.

\section{Terytorialne podejście do rozwoju w krajach pozaeuropejskich}

Także w kontekście międzynarodowym obserwuje się, że kilka krajów już inwestuje w budowanie zdolności rozwojowych poprzez politykę ukierunkowaną terytorialnie i innowacyjne partnerstwo. Należą do nich m.in. Australia, która wiele zainwestowała w politykę ukierunkowaną terytorialnie i budowę zdolności na poziomie lokalnym (Australian Centre of Excellence for Local Government ACELG 2009), Stany Zjednoczone, gdzie Amerykańskie Biuro ds. Miast (United States' Office of Urban Affairs) w 2010 roku rozpoczęło ogólny przegląd programów i polityk, które mają wpływ na społeczności lokalne [Douglas 2010], czy też Kanada, gdzie podejście liberalnego rządu Paula Martina wielu obserwatorów uznało, jako ukierunkowane terytorialnie kreowanie polityki, w której widoczne jest wprowadzenie innowacyjnych transferów na odnowę infrastruktury lokalnej. Celem przeglądu była pełniejsza integracja inwestycji federalnych podejmowanych w skali regionalnej po to, aby miały jak największy wpływ na procesy rozwoju lokalnego. Przegląd zainicjowany przez prezydenta Obamę jasno pokazał, że jest wiele możliwości działania na poziomie agend rządowych: likwidacja niepotrzebnych, niepowiązanych z konkretnymi terytoriami programów i zastąpienie ich innowacyjną polityką regionalną która poprawi podstawy ekonomiczne, zrównoważenie ekologiczne i szanse społeczne społeczności miast i wsi. Również - co warte odnotowania - w trakcie prac nad budżetem federalnym na rok 2012, wprowadzono kilka zmian ukierunkowujących terytorialnie istniejące polityki.

Zamiast podejścia odgórnego i nakazowego, polityka regionalna powinna prowadzić do zwiększenia innowacyjności, zdrowych zasad gospodarczych, zrównoważenia ekologicznego oraz rozwoju społecznego i kulturowego. N. Bradfrod zauważa wręcz, że Stany Zjednoczone zdały sobie sprawę, że kraje, które inwestują w miasta i społeczności lokalne najprawdopodobniej będą w czołówce postępowych zmian w XXI wieku [Bradford 2005].

Polityka ukierunkowana terytorialnie dla swojej skuteczności wymaga szerokiej współpracy podmiotów centralnych i regionalnych, wymaga poszukiwania specyficznych dla 


\section{Tabela 1. Główne filary reformy polityki spójności (propozycja raportu F. Barki)}

\begin{abstract}
Filar 1: Innowacyjne podejście w koncentracji na kluczowych priorytetach przy dotychczasowych kryteriach alokacji terytorialnej środ-

Skoncentrowanie 55-65\% funduszy na 3-4 kluczowych priorytetach, w tym jednym związanym z inkluzją społeczną. Podział środków przypisanych danemu krajowi pomiędzy regiony powinien być wynikiem wewnętrznych rozstrzygnięć i ustaleń pomiędzy państwami członkowskimi a ich regionami, w zależności od potrzeb i strategii. Niezmienione powinny pozostać kryteria kwalifikowania regionów do objęcia wsparciem (dotychczasowy próg 75\% PKB), co pozwoli na skoncentrowanie środków na najsłabiej rozwiniętych obszarach.
\end{abstract} ków finansowych

Filar 2: Nowe strategiczne ramy polityki spójności

Filar 3: Nowe stosunki umowne, implementacja i sprawozdawczość ukierunkowane na rezultaty

Filar 4: Sprawniejsze zarządzanie kluczowymi priorytetami
Należy wzmocnić dialog pomiędzy Komisją i państwami członkowskimi (lub, w niektórych przypadkach, regionami) dotyczący strategii oraz oprzeć go na Europejskich strategicznych ramach rozwoju, określających wyraźnie zasady, wskaźniki i poziomy docelowe, służące ocenie osiągniętych rezultatów.

Komisja i państwa członkowskie powinny opracować nowy typ stosunków umownych (Narodowa Strategiczna Umowa dla Rozwoju), koncentrujący się na skuteczności i zobowiązaniach możliwych do zweryfikowania.
W celu usprawnienia mechanizmów zarządzania kluczowymi priorytetami konieczna jest poprawa systemu monitorowania stopnia osiągania rezultatów oraz stosowanie zasady warunkowości w odniesieniu do ram instytucjonalnych. W tym
Filar 5: Promowanie zasady komplementarności oraz innowacyjnego i elastycznego wydatkowania środków

Filar 6: Promowanie eksperymentowania i mobilizowanie podmiotów lokalnych

Filar 7: Promowanie procesu uczenia się: w kierunku prospektywnej oceny oddziaływania interwencji

Filar 8: Przeorientowanie i wzmocnienie roli Komisji Europejskiej, jako ośrodka kompetencyjnego celu Komisja Europejska powinna położyć nacisk na opracowanie wysokiej jakości systemu wskaźników, określeniu ich wartości docelowych oraz stosowania instrumentów zmierzających do pełnego osiągania zamierzonych celów (system nagród, sankcji, a nawet kar finansowych dla państw członkowskich niestosujących się do wspólnych postanowień i rekomendacji Komisji).

Komisja powinna umocnić zasadę "dodatkowości” (gwarantująca, że państwa członkowskie nie zastępują środków państwowych środkami unijnymi), łącząc ją bezpośrednio z Paktem na rzecz Stabilności i Wzrostu. Do zapewnienia pożądanej innowacyjności i zwiększenia poziomu osiągania wartości dodanej zastosowanych środków potrzebne są z kolei zobowiązania umowne.

Komisja i państwa członkowskie powinny wspierać eksperymentowanie i dążenie do osiągnięcia zdrowej równowagi pomiędzy zachęcaniem lokalnych podmiotów do zaangażowania się, a wykorzystywaniem polityki przez różne grupy interesów.

Ulepszenie opracowywania i wdrażania metod szacowania rezultatów, jakie by osiągnięto, gdyby nie podjęto interwencji, pozwoliłoby lepiej zrozumieć, które działania są skuteczne w konkretnych sytuacjach, i oddziaływałoby dyscyplinująco na planowanie działań.

Dla zreformowanej polityki spójności konieczne jest poszerzanie wiedzy specjalistycznej urzędników Komisji oraz poprawa koordynacji pomiędzy dyrekcjami generalnymi (przede wszystkim DG REGIO (pol. DG EMPL, DG AGRI i DG MARE), tak by odpowiadało to większej roli i uprawnieniom Komisji w ramach polityki spójności. Oznaczałoby to znaczne inwestycje w zakresie zasobów ludzkich i zmian organizacyjnych. 
Filar 9: Zwiększenie efektywności zarządzania i kontroli finansowej
Osiągnięcie większej wydajności w zarządzaniu funduszami strukturalnymi poprzez realizację programu ciągłego upraszczania i rozważenie innych sposobów redukcji kosztów i obciążeń dla Komisji, państw członkowskich i beneficjentów. Dyrekcja Generalna ds. polityki regionalnej (DG REGIO) powinna być także wzmocniona kadrowo poprzez zasoby uwolnione w innych Dyrekcjach.

Filar 10: Wzmocnienie politycznego systemu kontroli i równowagi na najwyższym szczeblu
Raport Barki postuluje także stworzenie lepszego systemu kontroli i równowagi pomiędzy Komisją, Parlamentem Europejskim i Radą poprzez stworzenie oficjalnej Rady Polityki Spójności.

Źródło: opracowanie własne na podstawie F. Barca 2009

danego miejsca mechanizmów, które uruchomią wzrost nie tylko w konkretnej okolicy lub społeczności, ale także pozwolą na szersze oddziaływanie mechanizmów rozwojowych.

\section{Adaptacja terytorialnego podejścia do rozwoju przez politykę spójności UE}

Zintegrowane podejście terytorialne określa politykę spójności, jako politykę ukierunkowaną na wykorzystanie wewnętrznego potencjału rozwojowego, terytorialnych zasobów, w tym zasobów wiedzy oraz jako politykę pozwalającą na realizację interwencji odpowiadających współczesnym wyzwaniom rozwojowym, a zarazem dostosowanych do specyficznych uwarunkowań terytorialnych. Właściwe zdefiniowanie możliwości i potrzeb poszczególnych obszarów oznacza konieczność ścisłej współpracy władz centralnych z samorządami terytorialnymi, co oznacza większe zaangażowanie władz regionalnych i lokalnych w programowanie i wdrażanie polityki spójności. Nowa polityka spójności powinna (zdaniem autorów raportu Barki) w większym stopniu stanowić odpowiedź na specyficzne potrzeby terytoriów powiązane $\mathrm{z}$ endogenicznym potencjałem rozwojowym poszczególnych obszarów.

W raporcie Barki przedstawione zostały przesłanki, na których opiera się europejska polityka spójności oraz zalecenia dotyczące kompleksowej jej reformy na podstawie 10 „filarów" (tabela 1). Reforma spowodować ma stworzenie polityki w zakresie spójności gospodarczej i społecznej dopasowanej do specyficznych potrzeb często bardzo zróżnicowanych obszarów.

Jeden z ważniejszych postulatów zawartych w raporcie Barki dotyczy przyjęcia za podstawę polityki spójności Unii Europejskiej terytorialnego podejścia do rozwoju, określanego przez autora mianem polityki ukierunkowanej terytorialnie (place-based policy). Przyjęcie terytorialnego paradygmatu rozwoju uzasadnia objęcie polityką spójności całego obszaru UE, nie tylko regionów problemowych, będących przez wiele lat niemal wyłącznymi (nie licząc Europejskiego Funduszu Społecznego) beneficjentami funduszy strukturalnych. Pełniejsze wykorzystanie potencjału tkwiącego we wszystkich regionach, również tych najbogatszych, pozwolić ma na maksymalizację efektów polityki spójności [Słupińska 2016, s. 63]. 
Podejście terytorialne, charakteryzujące się zintegrowanym sposobem oddziaływania na rozwój terytorium wymaga także szerszego uwzględniania w innych politykach sektorowych UE wymiaru terytorialnego ${ }^{4}$.

\section{Podejście terytorialne w polityce spójności - wyzwania dla polskich regionów}

Bez wątpienia obecny kształt polityki spójności wzmacnia rolę regionów w jej implementacji. Z drugiej jednak strony, wymusza większą odpowiedzialność regionalnych administracji, których obowiązkiem jest stworzenie odpowiednich warunków do otrzymania wsparcia.

Dla polskich regionów nowy kształt polityki spójności oznacza pewne zmiany, kreuje zarówno nowe możliwości, jak i nowe wyzwania. Regiony mają większy wpływ na kształtowanie zawartości i na wdrażanie regionalnych programów operacyjnych, mają pewien udział w opracowywaniu umowy partnerskiej. Zmiany te dają regionom większą możliwość realizacji własnych priorytetów i strategii. Jednak zwiększenie odpowiedzialności i dyscypliny w działaniach władz publicznych, zaproponowane przez Komisję Europejską, oznaczają dla władz regionalnych i lokalnych konieczność podejmowania działań zapewniających spełnienie kryterium warunkowości (conditionality). Kryterium warunkowości oddziałuje także na władze centralne. Realizacja polityki spójności, zgodnie z zasadami określonymi przez Komisję Europejska, wymusza zarówno na władzach rządowych, jak i samorządowych konieczność podnoszenia jakości i efektywności krajowych i regionalnych polityk w obszarze rynku pracy, edukacji czy polityki społecznej5.

Dokumentem określającym strategię wdrażania funduszy europejskich w Polsce w okresie 2014-2020 jest Umowa Partnerstwa (UP), w której nasz kraj wskazuje, w jaki sposób chce zrealizować swoje cele rozwojowe z wykorzystaniem funduszy unijnych. Założenia Umowy Partnerstwa zostały przyjęte przez Rząd RP 15 stycznia 2013 roku ${ }^{6}$.

\footnotetext{
${ }^{4}$ Informacji o możliwych rozwiązaniach, pozwalających na „uterytorialnienie” polityk publicznych, dostarczają tzw. zasady metodologiczne (methodological principles), wypracowane i przyjęte przez Radę Unii Europejskiej w składzie ministrów ds. polityki spójności w ramach prac prezydencji francuskiej. W dokumencie znalazło się m.in. zalecenie dotyczące konieczności uwzględniania oddziaływania terytorialnego kluczowych strategii i polityk rozwojowych już na etapie ich planowania strategicznego. Innym postulatem jest poprawa komplementarności i powiązań pomiędzy kluczowymi strategiami i politykami sektorowymi a polityką spójności. W tym kontekście Rada Unii Europejskiej zaleca podjęcie działań prowadzących do pogłębienia wiedzy na temat oddziaływania terytorialnego kluczowych strategii i polityk rozwojowych oraz działań pozwalających na lepszy monitoring i ewaluację decyzji mających oddziaływanie terytorialne. Działania te, aby mogły być skuteczne, wymagają zorganizowania właściwej koordynacji zarówno na poziomie europejskim, jak i na poziomie krajowym, a także promowania podejścia terytorialnego i projektów terytorialnych w tych wszystkich politykach sektorowych, które mają silne oddziaływanie terytorialne (Contribution of the ministers in chargé of spatial planning and the cohesion policy gathered in Marseilles on 26 November 2008: Methodological contribution to the analysis of sector-based policies - recommendations for taking into account the territorial dimension in the key dossiers, [za:] Krajowa Strategia Rozwoju Regionalnego 2010-2020: Regiony, Miasta, Obszary wiejskie, 2010).

${ }^{5}$ Evidence-based Cohesion Policy and its role in achieving Europe 2020 objectives, 2011.

${ }^{6} \mathrm{~W}$ dokumencie wskazano m.in. rodzaje inwestycji, które będą mogły uzyskać wsparcie z funduszy unijnych, nakreślono układ programów operacyjnych, zarys systemu ich wdrażania, a także podział kompetencji w zakresie zarządzania funduszami europejskimi pomiędzy władzami rządowymi i samorządami regionalnymi.
} 
Umowa Partnerstwa definiuje koncepcję wdrażania funduszy unijnych w ramach realizacji trzech polityk Unii Europejskiej: polityki spójności, wspólnej polityki rolnej (WPR) i wspólnej polityki rybołówstwa (WPRyb). Instrumentami, poprzez które wdrażana będzie Umowa Partnerstwa są zarówno krajowe (KPO), jak i regionalne programy operacyjne (RPO). Umowa Partnerstwa wraz z programami operacyjnymi tworzą kompleksowy system krajowych dokumentów strategicznych. Umowa Partnerstwa to także dokument, w którym zostały określone oczekiwane rezultaty alokowanych środków oraz ramy finansowe realizacji Umowy. Na podstawie Umowy Partnerstwa możliwe było także określenie szczegółowej zawartości zarówno krajowych, jak i regionalnych programów operacyjnych [Słupińska 2012b].

Terytorialne podejście do wspierania rozwoju społeczno-gospodarczego odzwierciedlone jest zarówno w krajowych, jak i regionalnych programach operacyjnych ${ }^{7}$. Wszystkie interwencje przewidziane do realizacji w Umowie Partnerstwa, zgodnie z ujęciem terytorialnym rozwoju, zostały ściśle dopasowane do możliwości poszczególnych terytoriów. Na podstawie Krajowej Strategii Rozwoju Rregionalnego 2010-2020: Regiony, Miasta, Obszary wiejskie (Ministerstwo Rozwoju Regionalnego 2010), zidentyfikowano obszary strategicznej interwencji państwa (OSI), dla których przygotowane będą tzw. inicjatywy zintegrowane, łączące środki i instrumenty różnych polityk i funduszy unijnych.

Z perspektywy Polski szczególnie istotny jest terytorialny charakter nowej polityki spójności UE, której nasz kraj jest największym beneficjentem. Obecny okres programowania i wdrażania polityki spójności charakteryzuje się znacznym zwiększeniem środków, którymi zarządzają same regiony. $Z$ jednej strony oznacza to dla regionów więcej możliwości w zakresie definiowania i realizacji własnych priorytetów rozwojowych, z drugiej zaś strony oznacza większą odpowiedzialność za powierzone środki i wymusza w związku z tym wypracowanie koniecznych mechanizmów optymalizujących koordynację interwencji. Realizacja zadań związanych z wdrażaniem funduszy unijnych podzielona została pomiędzy władze rządowe i samorządowe według zasady subsydiarności, a instrumentem zapewniającym komplementarność podejmowanych działań będzie kontrakt terytorialny.

Problemem jednak jest wyjątkowa opieszałość w wydatkowaniu środków europejskich przez nasz kraj. W okresie 2014-2020 Polska ma do wykorzystania 82,5 mld euro z budżetu polityki spójności. Mimo „kryzysowego” budżetu Unii Europejskiej to więcej niż w poprzedniej perspektywie 2007-2013 (wówczas było to ok. 68 mld euro). Opóźnienie komentują także przedstawiciele rządu. Realizacja nowej perspektywy finansowej UE - w ramach polityki spójności - jest mocno opóźniona (...), uruchomienie programów operacyjnych jest opóźnione od sześciu do dwunastu miesięcy. To powoduje, że ten rok jest bardzo słaby, bo ze starej perspektywy unijnej rozliczamy środki, a pieniądze z nowej dopiero zaczynaja płynaćs. Do kwietnia 2016 r. Polska wydała nieco ponad 3 mld zł z funduszy UE, a tyle powinno być wydawane w skali miesiąca. Zgodnie z informacją prasową Ministerstwa Rozwoju z 26 lipca 2016 r., do 31 maja 2016 r. do Polski trafiło 752 mln euro. Jest to zaledwie 1\% alokacji dostępnej dla naszego kraju

\footnotetext{
${ }^{7}$ Więcej na ten temat autorka pisze w innym swoim artykule: M. Słupińska 2012b.

${ }^{8}$ Wypowiedź wiceministra rozwoju, Jerzego Kwiecińskiego podczas posiedzenia sejmowej komisji ds. Unii Europejskiej (kwiecień 2016) za: portalsamorządowy.pl
} 
w ramach perspektywy 2014-2020 (bez funduszy Europejskiej Współpracy Terytorialnej). Szczególny niepokój budzi brak postępów we wdrażaniu środków przeznaczonych na realizację dużych projektów infrastrukturalnych na poziomie centralnym. W zasadzie, aby móc mieć nadzieję na wykorzystanie przyznanych Polsce na ten cel funduszy, do końca 2016 r. powinny być rozpisane przetargi na realizację projektów infrastrukturalnych. Niestety informacji na ten temat nie ma na stronach rządowych, co pozwala na przypuszczenia, że przetargi nie są przygotowane. Niezwykle istotne jest obecnie dołożenie wszelkich starań, aby środki, które prawdopodobnie po raz ostatni w tak dużej kwocie zostały przyznane Polsce, zostały wykorzystane w pełni.

\section{Podsumowanie}

Lata badań teoretycznych rozwijanych wokół koncepcji terytorium zaowocowały sformułowaniem terytorialnego paradygmatu rozwoju, który stał się podstawą rozważań nad kierunkami reformy polityk rozwoju, prowadzonych zarówno przez instytucje międzynarodowe, jak i administracje rządowe w krajach europejskich i pozaeuropejskich. To terytorium, wraz z jego specyficznymi cechami, wewnętrznym zorganizowaniem, logiką i jakością wykształconych relacji społeczno-instytucjonalnych, stanowi bezpośrednie otoczenie przedsiębiorstw, stanowiąc zarazem jeden z głównych zasobów dla rozwoju podmiotów gospodarczych. Czynników budujących terytorium, takich jak zaufanie, wspólnota doświadczeń, kody zachowań, nie można wprowadzić w trybie uchwał czy rozporządzeń, są one skutkiem wieloletnich procesów doświadczanych i tworzonych przez określone społeczności. Można jednak - i należy - podejmować działania promujące wdrażanie mechanizmów decyzyjnych, budujących te cechy terytorialne, na które wpływ może i powinna mieć władza publiczna. Do takich cech należy chociażby kapitał relacyjny, skuteczne mechanizmy współzarządzania czy sposób sprawowania władzy, budujący zaufanie i sprzyjający rozwojowi prawidłowych relacji pomiędzy aktorami rozwoju.

Doświadczenia państw, które zdecydowały się na implementację podejścia terytorialnego do polityk i interwencji publicznych wskazują na celowość takich działan. Pozytywne efekty uzyskane dzięki „uterytorialnieniu” niektórych polityk pozwalają przypuszczać, że w kolejnych latach podejście terytorialne będzie adaptowane w coraz szerszej skali.

\section{Bibliografia}

Australian Centre of Excellence for Local Government (ACELG 2009), Project Plan 2009-2014, Centre for Local Government, University of Technology Sydney, Sydney.

Barca F., 2009, An Agenda For A Reformed Cohesion Policy. A place-based approach to meeting European Union challenges and expectations, Independent Report prepared at the request of Danuta Hübner, Commissioner for Regional Policy, 2009; http://ec.europa.eu/regional_policy/policy/future/pdf/report_barca_v0306.pdf [dostęp: listopad 2011]. 
Barczyk S., 2010, Przedsiębiorczy samorząd lokalny i jego instytucje, Wydawnictwo Akademii Ekonomicznej im. Karola Adamieckiego w Katowicach, Katowice.

Bradford N., 2005, Place-based Public Policy: Towards a New Urban and Community Agenda for Canada, Canadian Policy Research Networks INC, Ottawa.

Camagni R., 2008, Regional Competitiveness: Towards a Concept of Territorial Capital, [w:] R. Capello, R. Camagni, B. Chizzolini, U. Pratesi, Modelling Regional Scenarios for the Enlarged Europe. European Competitiveness and Global Strategies, Springer Berlin Heidelberg, s. 33-47.

Castells M., 2008, Społeczeństwo sieci, Wydawnictwo Naukowe PWN, Warszawa.

Douglas D., 2010, Place-Based Investments. Retrieved from Office of Urban Affairs; http:// www.whitehouse.gov/ blog/2010/06/30/place-based-investments.

Evidence-based Cohesion Policy and its role in achieving Europe 2020 objectives, 2011, Ministerstwo Rozwoju Regionalnego, Warszawa.

Florida R., 1995, Towards the Learning Region, „Futures”, 27,5, s. 527-536.

Jewtuchowicz A., 2005, Terytorium $i$ współczesne dylematy jego rozwoju, Wydawnictwo Uniwersytetu Łódzkiego, Łódź.

Krajowa Strategia Rozwoju Regionalnego 2010-2020: Regiony, Miasta, Obszary wiejskie, 2010, Ministerstwo Rozwoju Regionalnego, Warszawa.

Pietrzyk I., 2004, Globalizacja, integracja europejska a rozwój regionalny, [w:] A. Jewtuchowicz (red.), Wiedza, innowacyjność, przedsiębiorczość a rozwój regionalny, Wydawnictwo Uniwersytetu Łódzkiego, Łódź.

Pietrzyk I., 2013, Reforma europejskiej polityki spójności na lata 2014-2020, [w:] A. Nowakowska (red.), Zrozumieć terytorium. Idea i praktyka, Wydawnictwo Uniwersytetu Łódzkiego, Łódź.

Romer R., 1994, The Origins of Endogenous Growth, „The Journal of Economic Perspectives", 8,1 [za:] J. Szlachta i J. Zaleski 2009, Wptyw spójności terytorialnej na zmiany polityki strukturalnej Unii Europejskiej, „Gospodarka Narodowa”, 2009, 4, s. 91-110.

Słupińska M., 2012a, Integracja europejska czy dezintegracja - polityka spójności Unii Europejskiej w świetle teoretycznych modeli integracji, [w:] E. Molendowski (red.), Globalizacja i regionalizacja we wspótczesnym świecie, Wydawnictwo Uniwersytetu Ekonomicznego w Krakowie, Kraków.

Słupińska M., 2012b, Regiony w polityce spójności Unii Europejskiej w latach 2014-2020, [w:] E. Pancer-Cybulska i E. Szostak (red.), Polityka spójności w okresie 2014-2020 a rozwój regionów Europy, Prace Naukowe Uniwersytetu Ekonomicznego we Wrocławiu, 227.

Słupińska M., 2016, Terytorialne uwarunkowania rozwoju przedsiębiorstw. Terytorium - kapitat społeczny-governance, Wydawnictwo Uniwersytetu Łódzkiego, Łódź. 


\section{2 | TERYTORIALNY PARADYGMAT ROZWOJU W PRAKTYCE \\ Monika Słupińska}

\section{Territorial development paradigm in practice}

\section{ABSTRACT}

Cohesion policy plays a key role in the dynamics of the process of European integration. It is in a kind of „,barometer" of strength and direction of the integration process, around which in recent years there is a debate in Europe. This policy in the current programming period (2014-2020) has a clear "territorial dimension", i.e. adjust the nature of the support to the specific needs and certain territories.

The purpose of this article is to draw attention to the essence of the concept of territorial development paradigm and identify examples of its application for development policy. Particular attention in this context has been dedicated to European cohesion policy, the Polish regions are the biggest beneficiary.

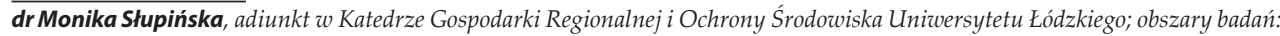
polityka regionalna UE i fundusze strukturalne, planowanie przestrzenne, terytorialne uwarunkowania rozwoju przedsiębiorstw. 